\title{
The Relationship between Leader Emotional Intelligence and Employee Job Satisfaction
}

\author{
Hlanganipai Ngirande \\ University of Limpopo, Department of Business Management, School of Economics \& Law \\ Private Bag $\times 1106$. Sovenga, 0727, South Africa \\ Email address: hlanganipai.ngirande@ul.ac.za
}

\section{Harry Tinashe Timothy}

University of Fort Hare, Department of Industrial Psychology, Private Bag x1314, Alice, 5200, South Africa Email address: harrytinashe@live.com

\author{
Doi:10.5901/mjss.2014.v5n6p35
}

\begin{abstract}
The concepts of Emotional intelligence and employee Job satisfaction are of high interest in the modern work environment. They serve as a competitive edge in personal and organizational life. However, there is little information known about the two variables' relationships especially in the South African electric power industry. The purpose of this study is to investigate the relationship between leader emotional intelligence and employee job satisfaction. A quantitative research design was utilised. The sample for this study consists of 92 randomly selected respondents from two strata (middle level organizational leaders and lower level employees). A self-administered questionnaire was administered to respondents; drawn from a selected Eskom branch in South Africa. The data collected was analysed using SPSS version 20.0. Correlation statistics revealed statistically significant relationship between leader emotional intelligence and employee job satisfaction. The value of the findings of this study lies in the explanatory utility of the identified relationships between leader emotional intelligence and employee job satisfaction.
\end{abstract}

Keywords: leader, emotional intelligence, employee job satisfaction, South Africa.

\section{Introduction and Background of the Study}

For organizations to survive in today's changing world they should maintain their competitive advantage through the use of the whole workforce. In order for the change to take place, the employees, and the leaders should be adapted to the environment, effective working and the continuous improvement of the processes and systems they use to achieve their objectives (Goleman, 2000). According to Goleman (2000), great leaders are the ones that are able to direct their subordinates and able to make the best of an individual to be visible and ignite his/her passion. However Coetzee and Schreuder (2013) pointed out that for a person to be a good leader, he/she must be healthier, less depressed, and more productive at work, and have better relationships with the subordinates. Goleman, Boyatzis and McKee (2002) also stated that great leaders are the ones that work through their emotions.

Emotional intelligence has been identified as the most important element that leads to effective leadership. Mayer, Salovey and Caruso (2008) defined emotional intelligence as the abilities to recognize and regulate the emotions one has and those of others, and with that information be in a position to make use of the emotions to direct one's thinking and actions. Therefore a good knowledge about others emotions and an ability to manage them can help a person to gain success and satisfaction in his/her work (Muhammad, 2009).

Employees who are under an emotionally intelligent superior are also likely to be emotionally stable and tend to be more satisfied with their work. Jorfi and Jorfi (2011) defined the term job satisfaction as an employee's affective reaction to his job in terms of how much it satisfies his desired outcome. Job satisfaction is an integral component of organizational climate and also an important element in management employee's relationship (Coertzee \& Schreuder, 2013). Given this, it is the positive emotional state that occurs when a person's job seems to fulfil important job values provided and when these values are compatible with one's needs (Mehrotra, 2005).

The fact that emotional intelligence is an important factor in organizational effectiveness, a leader is supposed to have greater emotional intelligence for him to be able to manage the organization more effectively. Although significant 
research has been conducted on leadership and employee job satisfaction, research on emotional intelligence is still relatively thin and the relationship between the emotional intelligence of the leader and the job satisfaction of the employee is less significant thus far.

\section{Problem Statement}

To understand how emotional intelligence of a leader affect the job satisfaction of an employee in the organization is very important, however not much research has been done to find out what impact does leaders 'emotional intelligence has on employee job satisfaction. It is still relatively unknown in the extent to which emotional intelligence affects effective leadership of an organisation (Palmer et al., 2001; Grunes, Gudmundsson \& Irmer, 2013). Regardless of much interest in the relationship between emotional intelligence and effective leadership, they are of the opinion that not much research has been conducted or published to support the relationship. In support of the argument, Ashkanasy and Daus (2002) assert that "the connection between emotional intelligence and employee job satisfaction is insufficient. Therefore this study seeks to explore how the employees perceive the emotional intelligence of their leaders and how it affects their job satisfaction.

\section{Objectives of the Study}

- To explore the concept of emotional intelligence;

- To investigate the impact of a leaders' emotional intelligence on employee job satisfaction and ;

- To give some recommendations to organisations on how they can put into practice emotional intelligence in their leaders as a strategy for improving employee job satisfaction.

\section{Research Hypothesis}

This study postulated that:

- HO: There is no relationship between leader emotional intelligence and employee job satisfaction.

- H1: There is a significant relationship between leader emotional intelligence and employee job satisfaction.

\section{Reviewing the Related Literature}

\subsection{Understanding the concept of Emotional Intelligence}

In spite of the fact that the study of emotional intelligence is relatively novel, definitions and theorists seeking to explain the concept of emotional intelligence are many. Salovey and Mayer, 1994) first proposed the concept of Emotional Intelligence. They defined it as "a form of social intelligence that involves the ability to monitor one's own and others' feelings and emotions, to discriminate among them, and to use this information to guide one's thinking and action." On the other hand, George (2000) pointed out that emotional intelligence is the ability, capacity, skill or in the case of the trait El model, a self-perceived grand ability to identify, assess, manage and control the emotions of one's self, of others, and of groups.

Although there are various definitions of El, two distinct approached exist in understanding the nature of EL. The ability approach mainly focuses on emotion-related cognitive ability to effectively join emotion and reasoning (Mayer \& Salovey, 1997). On the other hand, the trait approach, involves emotions-related behavioural dispositions and selfperceived abilities (Bar-On, 1997). Psychological studies have shown that understanding and controlling emotions play an important role in gratifying one's life and work (Coettzee \& Schreuder, 2013).

Emotions exist in a context; they are related to the situation, and one's goals, needs and wants. According to Brown, George-Curran and Smith (2003) the three main reasons why emotions are so vital in the work context are as follows: "they play a role in career development, they control one's actions and they motivate a person to act". Furthermore, emotions play a part in the decision making and the decisions may be related to career or the routine decision making. Therefore people have to be aware of their emotions and of the people around before making decisions that will affect them in the long run (Ashkanasy, Zebre \& Hartel, 2002). According to Bar-On (2000) "people who are emotionally and socially intelligent are able to understand and express themselves, to understand and relate well to others, and successfully cope with the demands of daily life". 


\subsection{The concept of Job Satisfaction}

The concept of job satisfaction is receiving increased consideration from the organisations nowadays, the reason being of its importance in the organisational effectiveness. With that in mind, managers feel with honour responsible for the maintenance of high levels of job satisfaction among the employees. Job satisfaction can be conceptualised as an employee's affective reaction to his job in terms of how much it satisfies his desired outcome (Jorfi \& Jorfi, 2011). Many organisations know that having a workforce that is highly satisfied with their work will contribute immensely towards the survival and effectiveness of the organisation. The feelings and behaviour that people exhibit on their job is also contributed by the nature of the environment outside the job (Hadebe, 2001).

Spector (2003) offered a different perspective about why people like or dislike their jobs. The antecedents of job satisfaction he identified were environmental aspects, personality variable or a combination of these. Job related features that impact on job satisfaction are the ones that make up the environmental aspects, for example, job characteristics, as well as various aspects of the organisation. A number of significant personal and environmental factors were distinguished by him such as work-family conflict, age, use of skills, occupational level, and job experience (Allen, Herst, Bruck, \& Sutton, 2000).

A work done by Terera and Ngirande (2014) revealed that training is positively associated with job satisfaction. Coetzee and Schreuder (2013) also found promotion as a tool to raise satisfaction. Kabungaidze, Ngirande and Mahlkatsana (2013) noted that job satisfaction is an attitude of an employee over a period of his job so the factors of satisfaction and dissatisfaction changes over time. Also, research studies shows that job satisfaction has a negative impact on employee turnover (Constance, Iris \& Colleen, 2011).

\subsection{Emotional intelligence and job satisfaction}

In their study on emotional intelligence and Job satisfaction, (Abi \& Jijo, 2012) found out that employees with high emotional intelligence will have higher job satisfaction. This is because the employees with higher emotional intelligence are able to develop strategies to overcome the possible consequences which may arise out of stress whereas those with less emotional intelligence won't be in a position to overcome stress situation. In addition, in a group setting employees with higher El will be able to influence the emotions of others in such a manner that, they will be able to boost their own as well as their co-workers' morale (Cooper \& Sawaf, 1997).

A leader employee with high emotional intelligence is able to respond appropriately to

workplace stress and to the emotional behavior of his or her subordinates. These abilities are anticipated to greatly enhance job satisfaction. Moreover, research has already shown that emotional intelligence leads to high job satisfaction, long-term mental health, better outcomes in work groups and leadership qualities and organizational success (Muhammad, 2009)

\subsection{Emotional Intelligence and Leadership}

Organisational and individual success is determined by the levels of emotional intelligence of the people. What this implies is that, when all the parties', i.e. the organisation and individual, emotional intelligence is developed both parties will benefit in the long run. In support to this, Langley (2000) pointed out that subordinates of the managers will be engaged in the work with passion, and on the other hand, managers would be receptive and open to the needs of the employees.

The investigation on the effectiveness of emotional intelligence to effective leadership is gaining a drive according to many authors and researchers (Palmer, et al., 2001; Watkin, 2000). According to Abraham (2000), with regard to the above, when a leader is emotionally intelligent, he/she will be more committed to the organisation. To further this idea Goleman (2000) adds that when leaders are emotionally intelligent they would be better performers in the workplace.

In support of Goleman (2000) s' study, Miller (1999) maintains that emotionally intelligent leaders bring great success to an organisation. In addition, an emotionally intelligent leader, through the use of interpersonal relationships, builds trust and teamwork in other employees, their decision making is enhanced by the use of their emotions and also the functioning of the organisation is improved when leaders make use of their positive emotions (George, 2000).

When emotions are managed in a correct way, they can lead to successful outcomes. However, the failure of leaders to control their own emotions, the quality of work, thinking and decision making process and the interaction with others will result in employee dissatisfaction (Palmer, Jansen \& Coetzee, 2006). Therefore for an organization to be successful, it requires people who are in a better position to motivate their own actions and those of their subordinates 
(Palmer et al., 2006).

\section{Research Methodology and Design}

A quantitative research approach was used. The population of the study comprised of Eskom employees at a selected Eastern Cape Province Eskom branch in South Africa. The total size of the population was $120(\mathrm{~N}=120)$. Using the RaoSoft sample size calculator, a minimum recommended sample size of 92 respondents was obtained.

In this study, the researchers utilized a probability sampling method, and more specifically stratified random sampling, as respondents were selected according to whether they are leaders or lower level employees. A selfadministered questionnaire was used to collect data from all the permanent employees obtained from the Human Resource Department as the sampling frame.

\subsection{Administering of the questionnaire}

Permission was requested from the HR Director of the organization to give out the questionnaires. The questionnaires were left with the HR officials for distribution. The anonymity and confidentiality of the information to be obtained from questionnaires was stressed to the HR department and to the respondents through a cover letter. To facilitate a good response rate, an agreement was made that the collection of data should take a period of three weeks.

\section{Data Processing and Analysis}

Analysis is the ordering and structuring of data to produce knowledge (Sharp, Peters \& Howard, 2002). The returned questionnaires were inspected to determine their level of acceptability. They were coded. The data was transferred to an Excel sheet. A statistical computer package, Statistics Package for Social Sciences (SPSS) version 20.0, was used to process the results. Descriptive statistics (e.g. means and standard deviations) was used to describe the data in summary form. Pearson product-moment correlation coefficient was used to measure the relationships between the variables, i.e. between emotional intelligence and employee job satisfaction.

\section{Results}

\subsection{Biographical information}

Table 1: Biographical information in percentages (\%)

\begin{tabular}{|l|l|c|}
\hline \multirow{2}{*}{ Gender } & Males & $67 \%$ \\
\cline { 2 - 3 } & Females & $33 \%$ \\
\hline \multirow{4}{*}{ Age } & $>20$ years & $3.44 \%$ \\
\cline { 2 - 3 } & $21-35$ years & $44.83 \%$ \\
\cline { 2 - 3 } & $36-45$ years & $27.57 \%$ \\
\cline { 2 - 3 } & $46-55$ years & $15.52 \%$ \\
\cline { 2 - 3 } & 56 years and above & $8.62 \%$ \\
\hline \multirow{3}{*}{ Level of Position } & & $58 \%$ \\
\hline \multirow{4}{*}{ Educational qualification } & Lower level position & $42 \%$ \\
\cline { 2 - 3 } & Leadership position & $25.86 \%$ \\
\hline & & $33.34 \%$ \\
\hline & Matric & $27.59 \%$ \\
\cline { 2 - 3 } & Diploma & $13.21 \%$ \\
\cline { 2 - 3 } & Undergraduate degree & \\
\cline { 2 - 3 } & Post graduate degree & \\
\hline
\end{tabular}

This study was based on a random sample 92 full time employees of a selected Eskom branch in South Africa. As shown in Table 1 above, Sixty seven percent of the participants were males. The majority of the participants (44.83\%) were in the age category 21-35 years. The results also showed that the majority, (58\%) of the participants were lower level employees and the remaining (42\%) were in the leadership positions. 
In terms of the educational levels of the respondents table 1 above showed that the majority of the respondents (35.34\%) had a diploma. Respondents with matric certificates and bachelor's degree were $25.86 \%$ and $27.59 \%$ of the sample, respectively. Respondents with a postgraduate certificate (11.21\%) constituted the lowest portion of the sample.

\subsection{Summary Descriptive statistics}

Table 2: Summary descriptive statistics

\begin{tabular}{lcc} 
& Mean & Standard. Deviation \\
\hline Age & 3.10 & .841 \\
Educational qualification & 2.21 & .701 \\
Position & 2.47 & .506 \\
Tenure & 2.45 & .677 \\
Emotional intelligence & 4.313 & .4895 \\
\hline Job satisfaction & 4.1313 & .63546 \\
\hline
\end{tabular}

Note: $\mathrm{N}=92$.

Table 2 presents means, standard deviation of the variables (age, educational qualification, position, tenure, emotional intelligence and job satisfaction) considered in this study. The study showed a gender distribution of 61 males and 31 females aged 21-35 years ( $M=3.10$ years; $S D=0.841)$. An average respondent had about a tenure of 6 years $(M=2.45$ years; $S D=0.677)$ in the organization. The results also indicated a mean and standard deviation of $(M=2.47 ; S D=0.506)$ for employee position variable. This showed that 53 the participants occupied lower level positions while 39 occupied leadership positions. The results also showed a mean score of 4.313 and a standard deviation of 0.4895 for Emotional Intelligence and a mean score of 4.1313 with a standard deviation of 0.6355 for average job satisfaction respectively.

\subsection{Inferential statistics (Hypothesis testing).}

Person product moment correlations are presented in table 3 below. It must be recalled that the study hypothesized that there is a relationship between emotional intelligence and employee job satisfaction. Emotional intelligence and job satisfaction with specific reference to (pay, promotion, coworker and supervision) showed a positive significant relationship to job satisfaction $(r=0.621 ; p<0.003)$. Given the above results, which indicated a significant relationship between the independent variable (leader emotional intelligence) and the dependent variable (job satisfaction), the study rejected the null hypothesis and accept the alternative hypothesis. This means that an increase in leader emotional intelligence will result in an increase in employee job satisfaction in an organization.

Table 3: Relationship between Emotional Intelligence and Job satisfaction

\begin{tabular}{|c|c|c|c|}
\hline \multicolumn{4}{|c|}{ Correlations } \\
\hline & & Leader Emotional Intelligence & Employee Job Satisfaction \\
\hline \multirow{3}{*}{ Leader Emotional Intelligence } & Pearson Correlation & 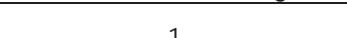 & $.621^{* *}$ \\
\hline & Sig. (2-tailed) & 1 & .003 \\
\hline & $\mathrm{N}$ & 92 & 92 \\
\hline \multirow{3}{*}{ Employee Job Satisfaction } & Pearson Correlation & $.621^{* *}$ & \multirow{2}{*}{1} \\
\hline & Sig. (2-tailed) & .003 & \\
\hline & $\mathrm{N}$ & 92 & 92 \\
\hline
\end{tabular}

\section{Discussion and Conclusion}

The present study extends an emerging body of research on the links between emotional intelligence and employee job satisfaction. The research results showed that the majority of the participants were males occupying lower level positions. The results also indicated that most of the respondents had a diploma during the time of the study. The reason of having the majority of the participants holding diplomas might be because of the nature of the job which is technical in nature. Therefore most of the skills are acquired on the job rather than in a class/lecture.

Importantly, the results also showed a positive significant relationship between leader emotional intelligence and employee job satisfaction. The findings of the correlation analysis imply that leader's level of greater emotional 
intelligence may lead to higher employee job satisfaction. Leaders who are emotionally intelligent are likely to make good decisions in the workplace which in turn will boost their subordinate's job satisfaction.

The research findings concur with Lopes, Grewall, Kadish, Gall and Salovey (2006)s` results which demonstrated convincingly that emotional intelligence is an important personality-level predictor of job satisfaction. Furthermore, previous studies have found a strong relationship between emotional intelligence and job satisfaction (Palmer et al., 2006).Therefore leaders should be very emotionally intelligent so as to keep their subordinate's level of satisfaction high and in turn, this will benefit the organization in meeting its short term and long term goals.

\section{References}

Abi, E., \& Jijo, G. (2012). "Emotional intelligence and job satisfaction: A correlation study," International journal Research journal of commerce \& Behavioural science, 1 (4), 37-41.

Abraham, R. (1999). Emotional Intelligence in Organisations: A Conceptualisation. Genetic, Social and General Psychology Monographs, 125 (2), 209-224.

Abraham, R. (2000). The Role of Job Control as a Moderator of Emotion Dissonance and Emotional Intelligence-Outcome Relationships. Journal of Psychology, 134 (2), 169.

Allen, T. D., Herst, D. E. L., Bruck, C. S., \& Sutton, M. (2000). Consequences associated with work to family conflict: A review and agenda for future research. Journal of Occupational Health Psychology, 5, 278-308.

Ashkanasy, N. M., \& Daus, C. S. (2002); Emotion in the workplace: The new challenge for managers. Academy of Management Executive, 16 (1).

Ashkanasy, N. M., Zebre, W. J. \& Hartel, C. E. J. (2002). Managing emotions in the workplace. New York: Sharpe.

Bar-On, R. (1997). Bar-On Emotional Quotient Inventory-Technical Manual. Toronto: Multi-Health Systems.

Bar-On, R. (2000). Emotional and social intelligence: Insights from the emotional quotient inventory. In R. Bar-On \& J. D. A. Parker (Eds). Handbook of emotional intelligence. San Francisco.

Brown, C., George-Curran, R. \& Smith, M.L. (2003). The role of emotional intelligence in the career commitment and decision-making process. Journal of Career Assessment, 11 (4), 379-392.

Coetzee, M. \& Schreuder, A.M.G. (2013). Career anchors as a meta-capacity in career development. Dordrecht: Springer International.

Constance. L. C., Iris. A. P. \&Colleen. A. R. (2011). Job Satisfaction and Career Commitment Among Alzheimer's Care Providers: Addressing Turnover and Improving Staff Empowerment. American Journal of Alzheimer's disease and Other Dementias, 26(7): 521-527.

Cooper, R.K. \& Sawaf, A. (2000). Executive EQ: Emotional intelligence in business. New York: Texere Publishing Limited.

George, J.M. (2000). Emotions and leadership: The Role of Emotional Intelligence. Human Relations, 53, 1027-1055.

Golem an, D. (2000). Leadership that gets results. Harvard Business Review.

Goleman, D., Boyatzis, R.E., \& McKee, A. (2002). Primal leadership: Realizing the Power of Emotional intelligence. Boston: Harvard Business School Publishing.

Grunes, P., Gudmundsson, A., \& Irmer, B. (2013). To what extent is the Mayer and Salovey (1997) model of emotional intelligence a useful predictor of leadership style and perceived leadership outcomes in Australian educational institutions? Educational Management Administration Leadership, 1-25.

Hadebe, T.P. (2001). Relationship between motivation and job satisfaction of employees at Vista Information Services. (M.A. Dissertation, Rand Afrikaans University, Johannesburg).

Jorfi, H. \& Jorfi,S. (2011). Strategic Operations Management: Investigating the Factors Impacting Communication Effectiveness and Job Satisfaction. Social and Behavioral Sciences, 24.

Kabungaidze, T., Mahlatshana, N., \& Ngirande, H. (2013). The impact of Job Satisfaction and Some Demographic Variables on Employee Turnover Intentions. International Journal of Business Administration, 4, (1):53-65.

Langley, A. L. (2000). Emotional Intelligence - a new evaluation for management development. Career Development International, 5 (3), $177-183$.

Lopes, P. N., Grewal, D., Kadis, J., Gall, M., \& Salovey, P. (2006). Evidence that emotional intelligence is related to job performance and affect and attitudes at work. Psicothema, 18, 132-138.

Mayer, J.D., \& Salovey, P. (1997). What is emotional intelligence? Implications for educators. New York: Basic Books.

Mayer, J.D., Salovey, P. \& Caruso, D.R. (2008). Emotional Intelligence a new ability or eclectic traits? (Electronic Version). American Psychologist $63(6)$.

Mehrotra, A. (2005). Leadership Styles of Principals - Authoritarian and Task Oriented. Mittal Pub, xv, 128 -134.

Miller, M. (1999). Emotional intelligence helps managers succeed. Credit Union Magazine, 65, 25-26.

Muhammad, M. A. (2009). The Relationships between the Emotional Intelligence and Job Satisfaction: Empirical Findings from Higher Education Institution in Malaysia. Journal of Management and Social Sciences, 5(2), 124-139.

Palmer, P., Jansen, C. A., \& Coetzee, M. (2006). Perceptions of South African managers' emotional intelligence: A preliminary investigation. Southern African Business Review, 10(1), 91-110.

Palmer, B., Walls, M., Burgess, Z. \& Stough, C. 2001. "Emotional intelligence and effective leadership", Leadership \& Organization Development Journal, 22(20): 1-7.

Sharp, J. A., Peters, J. \& Howard, K. (2002). The management of a student research project. Gower, Aldershot. England.

Spector, P.E. (2003). Industrial and organizational psychology - Research and practice (3rd ed.). New York: John Wiley \& Sons, Inc.

Terera, S. R. \& Ngirande, H. (2014). The Impact of Rewards on Job Satisfaction and Employee Retention. Mediterranean Journal of Social Sciences, 5(1): 481-487

Wade, C. \& Tavris, C. (2006). Psychology, (8th ed.). Upper Saddle River, NJ: Pearson Prentice Hall.

Watkin, C. (2000). Developing emotional intelligence. International Journal of Selection and Assessment, 8: 89-92. 